Sains Malaysiana 50(2)(2021): 287-300

http://dx.doi.org/10.17576/jsm-2021-5002-02

\title{
Shear Failure Mechanism and Acoustic Emission Characteristics of Jointed Rock- Like Specimens
}

(Mekanisme Kegagalan Ricih dan Pencirian Pancaran Akustik pada Spesimen Seakan Batuan Berkekar)

\author{
YuXin BAn, Qiang XiE*, Xiang Fu*, Rini Asnida Abdullah \& JingJing Wang
}

\begin{abstract}
Evidence indicate that the stability of rock mass is highly associated with the shear behaviours of jointed surfaces under the effect of in situ stress conditions. Understanding the shear failure mechanism of jointed surface has great significance for tunneling and drilling engineering. Direct shear tests were conducted on jointed rock-like specimens to investigate the influence of joint roughness and normal stress on shear failure characteristics. In the present study, regular triangular sawtooth was produced to simulate different asperities. Based on the direct shear test, the specimens exhibited four types of failure modes: damage tend to occur on the sawtooth tips under low normal stress; whereas damage occurred on a large scale under high normal stress; a localized region of the sawtooth was worn when the dilation angle was small; meanwhile the sawtooth tips or base were cut off when the dilation angle was large. In addition, Acoustic Emission (AE) technology was adopted to synchronously monitor the development of cracks during testing. Further attempt has been carried out to simulate the crack initiation, propagation and coalescence using Particle Flow Code (PFC). The numerical model has successfully verified and explained the crack behaviors determined by the shear failure mechanism in the physical test. Additionally, the irregular profile was introduced in the PFC, it was found that the failure behavior in sawtooth profile has established a good conclusion to fully understand the failure mechanism in the irregular profile. This work can provide some reference for evaluating the behavior of underground engineering composed of jointed rock masses during the shearing.
\end{abstract}

Keywords: Acoustic emission; failure mode; joint surface; particle flow code (PFC) simulation; shear failure mechanism

\section{ABSTRAK}

Bukti telah menunjukkan bahawa kestabilan jisim batuan berkaitan dengan sifat ricih bagi permukaan berkekar disebabkan oleh keadaan tekanan in situ. Memahami mekanisme kegagalan ricih pada permukaan berkekar mempunyai kepentingan besar dalam kejuruteraan terowong dan penggerudian. Ujian ricih secara langsung telah dijalankan pada spesimen seakan batuan berkekar untuk mengkaji pengaruh kekasaran kekar dan tekanan normal pada ciri-ciri kegagalan ricih. Dalam uji kaji ini, gigi gergaji segitiga biasa dihasilkan untuk mensimulasikan asperiti yang berbeza. Hasil uji kaji ricih secara langsung menunjukkan empat jenis mod kegagalan: kerosakan cenderung berlaku pada hujung gigi-gergaji di bawah tekanan normal yang rendah; manakala kerosakan berlaku pada skala besar apabila dikenakan tekanan normal yang tinggi; kawasan setempat pada gigi gergaji didapati menjadi haus pada sudut perkembangan gigi gergaji yang kecil; sedangkan hujung atau pangkal gigi gergaji terpotong ketika sudut perkembangan gigi gergaji yang besar. Di samping itu, teknologi pancaran akustik (AE) juga digunakan untuk memantau perkembangan retakan semasa ujian. Selanjutnya, inisiasi, perambatan dan petautan retakan disimulasikan secara berangka menggunakan kod aliran zarah (PFC). Model berangka telah berjaya mengesah dan menjelaskan kelakuan retakan yang berlaku semasa kegagalan ricih pada uji kaji fizikal. Tambahan lagi, profil ketaksekataan telah diperkenalkan di dalam PFC dan didapati sifat kegagalan pada profil gigi gergaji telah menghasilkan kesimpulan yang baik dalam memahami mekanisme kegagalan ricih pada profil tak sekata. Hasil kajian ini akan dapat menjadi rujukan untuk menilai sifat kejuruteraan bawah tanah yang terdiri daripada jisim batuan berkekar semasa ricihan.

Kata kunci: Mekanisme kegagalan ricih; mod kegagalan; pancaran akustik; permukaan kekar; simulasi kod aliran zarah (PFC)

\section{INTRODUCTION}

A rock mass is composed of joints, fissures, faults, and other types of geological discontinuities (Bandis et al. 1983; Barton et al. 1985). These discontinuities affect the mechanical behaviour, including deformation and stability of a rock mass. Complicated geological issues, such as shear slip failure along the joint surface, are frequently observed in various geoengineering systems (Grasselli et al. 2002). In the construction of tunnels, the stress redistribution around the cave is affected by the anisotropy of the rock 
mass induced by these discontinuities (Zhang et al. 2017). In the oil and gas industry, borehole instability leads to production accidents and excess maintenance expenditures (Meier et al. 2015). Under the effect of high in situ stress, the joint and its connections may contribute significantly to large-scale instability and eventually lead to considerable damage to the underground engineering structure. Rafek et al. (2019) identified the slope stability by measuring the average peak friction angle of the discontinuity surface with different Joint Roughness Coefficient (JRC).

Previous studies focused on the mechanical behaviour of jointed rock samples (Barton 1973; Barton \& Choubey 1977; Rafek et al. 2014). For example, Oh and Lim (2010) proposed a constitutive model for predicting rock strength while considering the influence of joint expansion. Similar studies on shear strength and residual strength prediction were also observed in the work of Casagrande et al. (2018) and Liu et al. (2017). Shrivastava and Rao (2018) noted that joint roughness was one of the most important parameters that affected the shear strength of rock joints. Investigation of the influence of joint roughness on the mechanical properties of jointed rock samples have also been adequately studied. Azinfar et al. (2019) established an optical evaluation system to assess 3D roughness; they performed direct shear tests to verify their method. Giwelli et al. (2014) tested the shear behaviour of fractures of different sizes and found that increasing joint roughness had a negative effect on peak shear strength. Serasa et al. (2017) estimate peak friction angle of limestone discontinuity surfaces by measuring the JRC values.

In related researches, joint roughness is usually simplified into regular geometric shapes, such as continuous triangular sawtooth, continuous rectangular the corresponding (Cui 2019; Gu et al. 2003). Liu et al. (2018) carved multi-level triangular asperities to simulate first-order and second-order roughness and suggested that loading cycles influenced the damage mechanism.

The Acoustic Emission (AE) method is widely used as an indirect technology to detect the activity of cracks in specimens observed in laboratory tests (Ban et al. 2020; Khazaei et al. 2015). AE is defined as a transient elastic waveform generated by the release of accumulated localised energy typically induced by microcrack initiation or expansion (Fu et al. 2015; Zhou et al. 2018). Previous studies with AE experiments in rocks have confirmed that crack initiation and propagation are highly associated with AE parameter characteristics, such as $\mathrm{AE}$ counts, cumulative $\mathrm{AE}$ counts and cumulative $\mathrm{AE}$ energy.

In recent years, numerical tests based on the Discrete Element Method (DEM) have become an important means to reproduce the crack growth process and showed the shear mechanisms (Cho et al. 2008; Hazzard et al. 2002). Compared with the traditional Finite Element Method (FEM) and the Extended Finite Element Method (XFEM), DEM simulations have unique advantages in evaluating the evolution activity of cracks and showed failure mechanisms. The PFC model is also appropriate for simulating crack propagation issues in anisotropic rock. Emphasis on joint roughness gradually switched from strength prediction to crack propagation characteristics. Some researchers (Asadi et al. 2012; Bahaaddini 2017) investigated the asperity degradation mechanism of jointed rock samples by establishing $\mathrm{PFC}^{2 \mathrm{D}}$ models. Park and Song (2009) simulated rock joints with different JRC values via $\mathrm{PFC}^{3 \mathrm{D}}$, and their results were well fitted with the theoretical shear model.

Although an abundance of work has been performed, shear failure modes and damage mechanisms on joint surfaces under a constant normal load are not fully understood. Furthermore, a comprehensive evaluation of $\mathrm{AE}$ characteristics and $\mathrm{PFC}$ simulations is lacking (Mpalaskas et al. 2016). As a consequence, the main objective of this work was to investigate failure modes and damage processes of jointed rock-like specimens to increase understanding of the shear failure mechanism. Both the effects of joint surface roughness and normal stress were considered in the present study. For this purpose, a series of direct shear tests were carried out on rock-like specimens in addition to the AE method, and the tests were modelled with $\mathrm{PFC}^{2 \mathrm{D}}$. Note that rock with different lithology may give different joint surface roughness behaviour, the results of shear tests are usually complicated although the specimens are taken from the same block of rock (Patton 1966), thus, the artificial material made from cement is used to simulate soft rock. The present study aims to evaluate the regularities of shear properties on the joint surface.

\section{Materials AND Methods}

\section{EQUIPMENT}

Shear tests were carried out with the YZW-30 rock direct shear apparatus (Figure 1(a)). The testing equipment was composed of a loading system, a shearing system, and a control system. The loading system comprised a horizontal loading device and a vertical loading device to provide shear and normal stress. Both horizontal and shear stress were applied via hydraulics. Two fixtures were designed and fabricated from Q345 steel. A Linear Variable Differential Transformer (LVDT) was mounted on the vertical and horizontal directions to monitor the normal and shear displacements of the specimen. 
AE signals were synchronously monitored with an 8 -channel DS2 system. Two RS-2A probes $(\Phi 18.8 \times 50$ $\mathrm{mm}$ ) were pasted on the front surfaces (upper part) and the back surface (lower part) of the specimen. The signal acquisition frequency of the sensors ranged from 50 to
$400 \mathrm{kHz}$, and the applicable temperature ranged from -20 to $130{ }^{\circ} \mathrm{C}$. The signals were amplified with a $40 \mathrm{~dB}$ preamplifier. The sampling rate was $3 \mathrm{MHz}$, and the threshold voltage was set at $100 \mathrm{mV}$ to reduce noise.
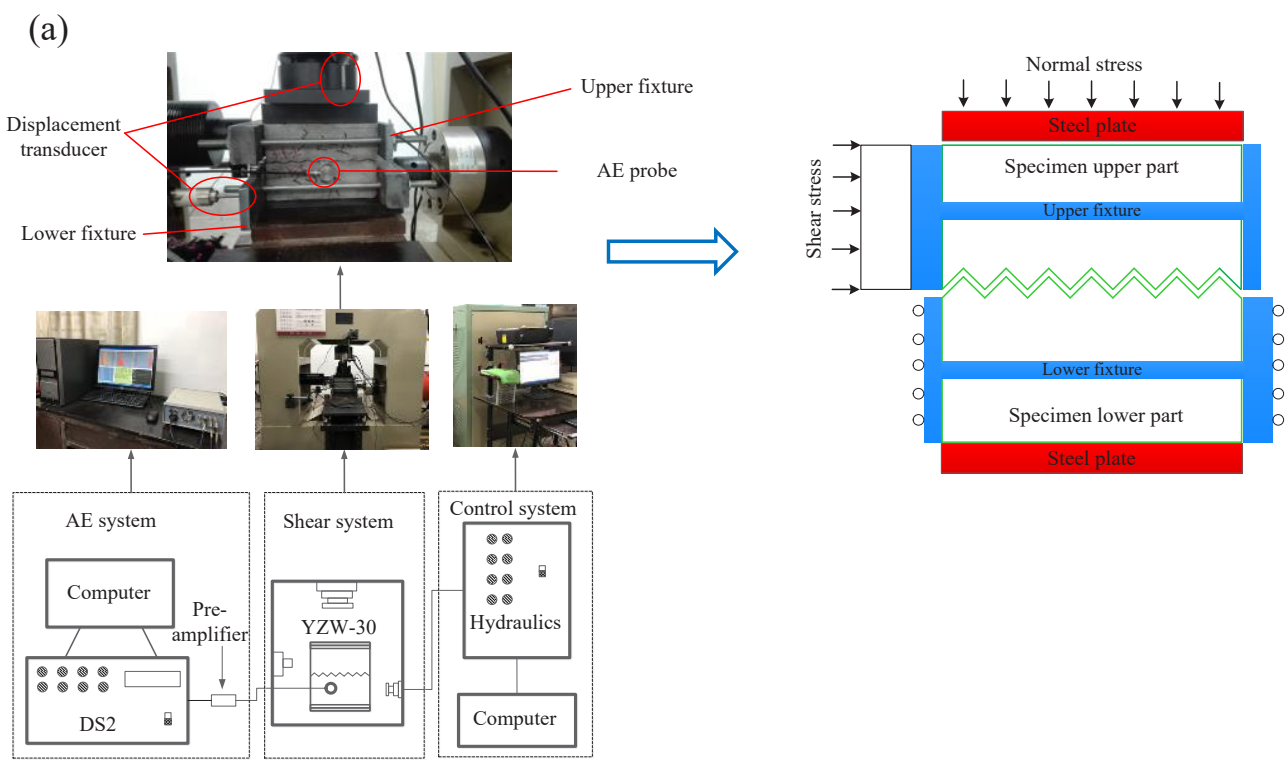

(b)
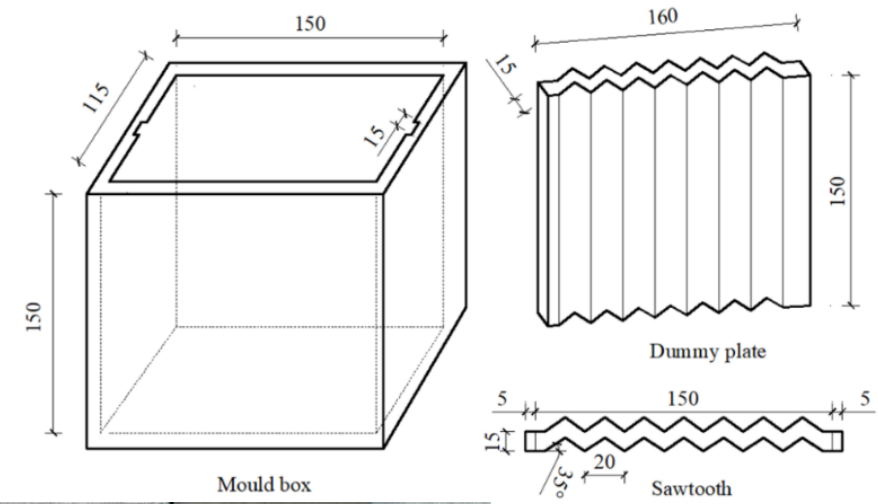

(c)

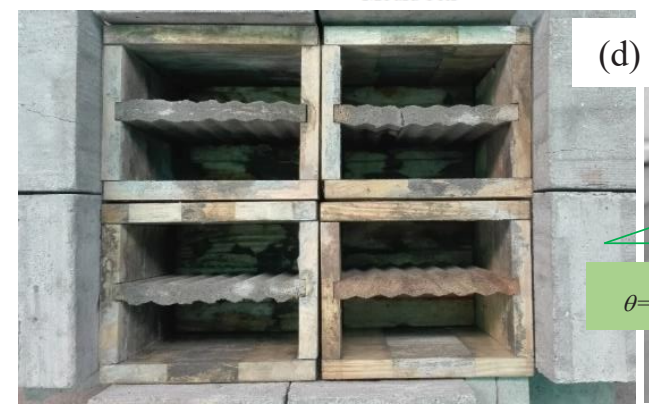

(d)

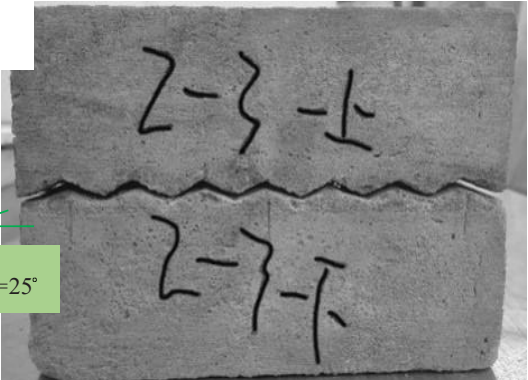

FIGURE 1. (a) Experimental direct shear system. (b) Design of the mould and dummy plate. (c) Moulds surrounded and fixed with waste concrete cubes to prevent deformation while pouring the cement mortar. (d) Upper and lower parts of the $25^{\circ}$ specimen 


\section{SPECIMEN PREPARATION AND LOADING SCHEME}

In the study of jointed specimens, synthetic materials such as gypsum and cement mortar are usually adopted to exclude random geological variables. In this experiment, cement mortar was adopted. The preparation process of the specimens is shown in Figure 1(b). A dummy plate was set in the middle of the mould box to form regular sawtooth. There were seven triangular sawtooths on each joint surface. The dilation angle $\theta$ of the sawtooth with respect to its base was set at $15,25,35$, and $45^{\circ}$ (Barton \& Choubey 1977).
The rock-like specimen was made with fine-grained sand (particle size $<1.25 \mathrm{~mm}$ ), P42.5 Portland cement, and water. The mass ratio of cement, sand, and water was $1: 2: 0.5$, respectively. A thin layer of machine oil was painted evenly inside the mould box to facilitate demoulding. The compaction of the rock-like specimen was controlled to ensure that all specimens possessed similar uniaxial compression strength. The specimens were cured under standard temperature and humidity for 28 days as suggested by the ISRM standard (Muralha et al. 2014; Wang et al. 2018).

TABLE 1. Specimen grouping and loading scheme

\begin{tabular}{cccccc}
\hline $\begin{array}{c}\text { Dilation angle } \\
\theta\left(^{\circ}\right)\end{array}$ & No. & $\begin{array}{c}\text { Normal } \\
\text { stress } \\
(\mathrm{MPa})\end{array}$ & $\begin{array}{c}\text { Dilation } \\
\text { angle } \\
\theta\left({ }^{\circ}\right)\end{array}$ & No. & $\begin{array}{c}\text { Normal stress } \\
(\mathrm{MPa})\end{array}$ \\
\cline { 2 - 5 } & $1-1$ & 0.5 & & $3-1$ & 0.5 \\
15 & $1-2$ & 1 & 35 & $3-2$ & 1 \\
& $1-3$ & 3 & & $3-3$ & 3 \\
& $1-4$ & 5 & & $3-4$ & 5 \\
\hline 25 & $2-1$ & 0.5 & & $4-1$ & 0.5 \\
& $2-2$ & 1 & 45 & $4-2$ & 1 \\
& $2-3$ & 3 & & $4-3$ & 3 \\
\hline
\end{tabular}

The uniaxial compressive strength of three complete specimens produced from the same preparation batch was $10 \mathrm{MPa}$ and the average elastic modulus was approximate $3.4 \mathrm{GPa}$. The shear specimens were divided into four groups according to the dilation angle $\theta$, with three samples in each group. Due to better uniformity and lower discreteness in cement mortar specimens, only one representative result from each group is presented in Table 1. The normal stress changes from a relatively low value to a relatively high value. Note that normal stress beyond $60 \%$ of the uniaxial compression strength may cause irreversible plastic compression-shear damage. Consequently, four levels of normal stress corresponding to $5,10,30$, and $50 \%$ of the uniaxial compressive strength of the complete specimen (i.e. $0.5,1,3$, and 5 $\mathrm{MPa}$, respectively) were applied in each group. Both the loading rates for normal and shear stresses were $0.5 \mathrm{kN} / \mathrm{s}$. The normal stress was held after reaching the set value, at which point, shear stress was imposed on the sample.

\section{RESULTS AND DISCUSSION}

\section{TEST RESULTS}

The shear stress history is a function of normal stress and joint surface roughness. The shear stress-shear displacement curves of the specimens are shown in Figure 2(a), the typical specimen failure modes are shown in Figure 2(b), and Figure 2(c) shows the schematic diagram of the sawtooth structure and the damage location. There were four kinds of shear stress-shear displacement curve profiles, corresponding to four types of shear failure modes. 

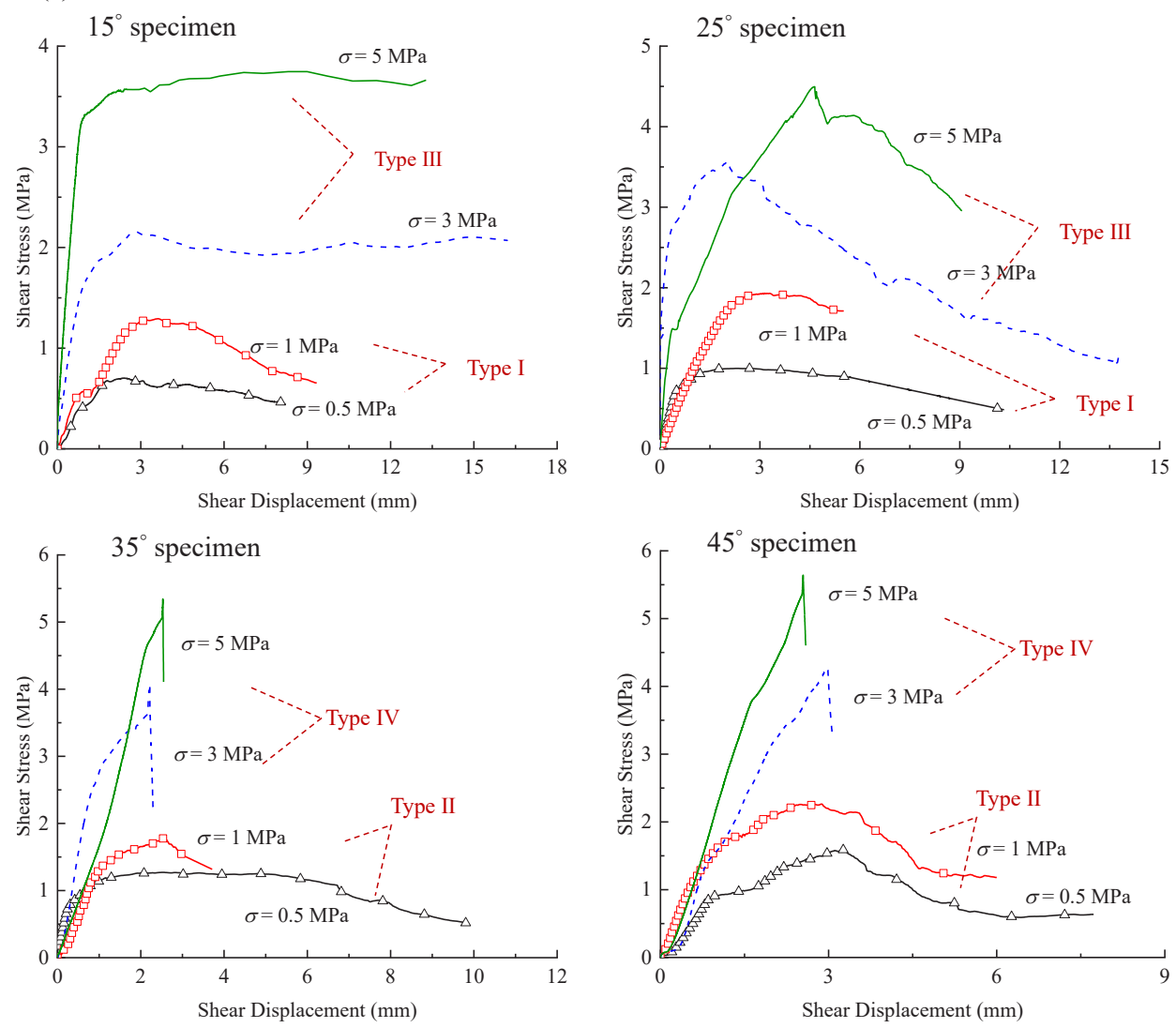

(b)
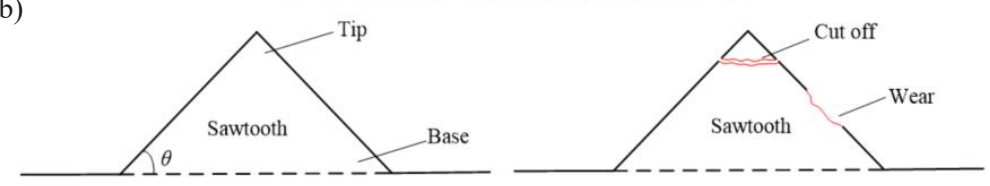

(c)

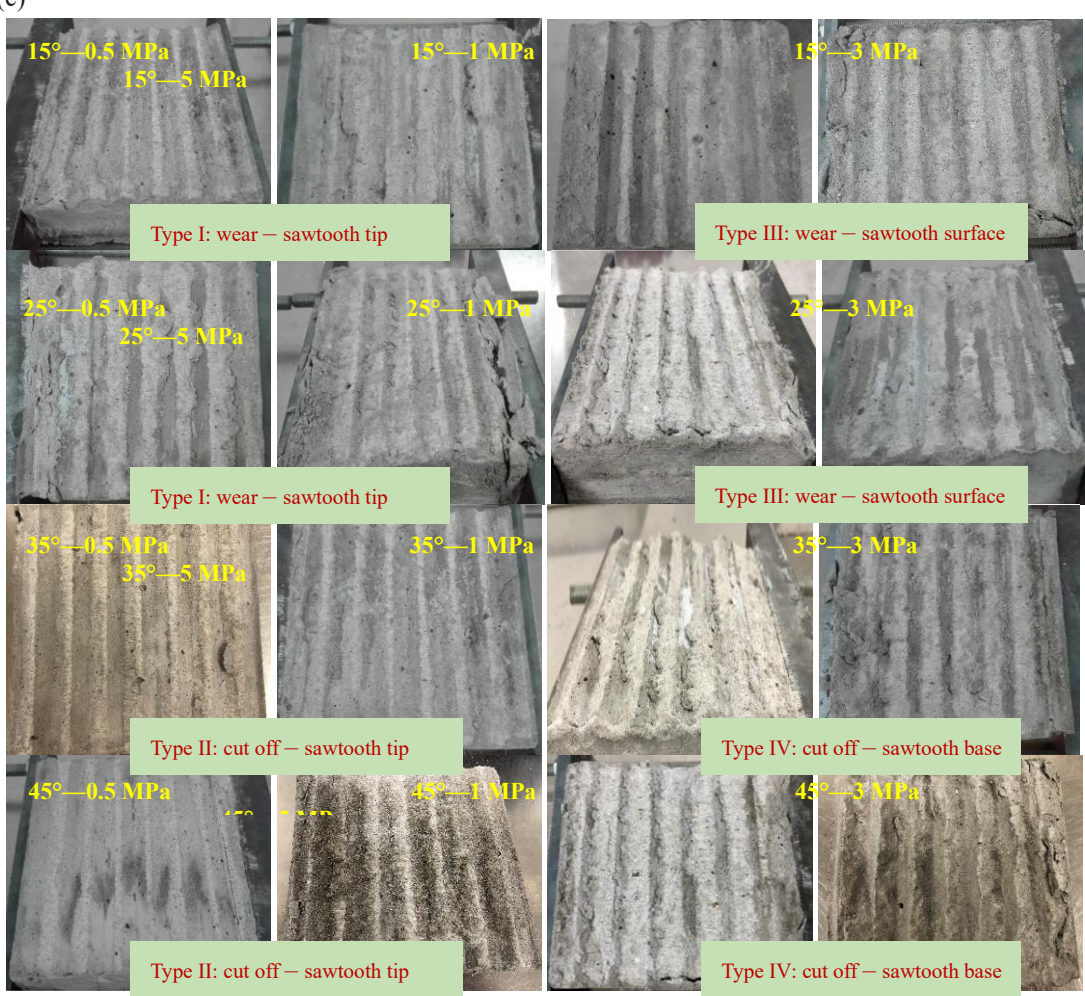

FIGURE 2. (a) Shear stress-shear displacement curves for the specimens. (b) Schematic diagram of the sawtooth structure and the corresponding damage location. (c) Images of the four types of failure modes 
Failure mode Type I Under the action of low normal stress ( 0.5 and $1 \mathrm{MPa})$, the shear strength of the specimens with low dilation angles $\left(15^{\circ}\right.$ and $\left.25^{\circ}\right)$ was relatively low, approximately $1 \mathrm{MPa}$. The shear stress of these specimens decreased smoothly after reaching the peak shear stress, and the specimens exhibited residual shear strength. The maximum shear displacement on these specimens was approximately $9 \mathrm{~mm}$. The sawtooth tips of the jointed specimens were slightly worn.

Failure mode Type II Under the effect of low normal stress ( 0.5 and $1 \mathrm{MPa})$, the shear behaviour of the specimens with high dilation angles $\left(35^{\circ}\right.$ and $\left.45^{\circ}\right)$ was similar to that of the specimens exhibiting failure mode Type I. These samples also exhibited residual shear strength. The decrease in shear stress fluctuated after reaching the peak shear stress. At this time, the sawtooth tips of the jointed specimens were cut off.

Failure mode Type III Under the action of high normal stress ( 3 and $5 \mathrm{MPa}$ ), the shear strength of the specimen with low dilation angles $\left(15^{\circ}\right.$ and $\left.25^{\circ}\right)$ increased to approximate 2-4.5 MPa. The shear stress fluctuated within a narrow range after reaching peak shear strength. The detected maximum shear displacement of these specimens was $15.58 \mathrm{~mm}$, which was the longest among all the specimens. The sawtooth surfaces were extensively worn over a large area. This type of joint surface continued to resist shear after the specimen was initially damaged.

Failure mode Type IV Under the effect of high normal stress (3 and $5 \mathrm{MPa}$ ), the shear strength of specimens with high dilation angles was highest (approximately 5.6 $\mathrm{MPa}$ ). This type of specimen was unique because the shear

(a) Type I

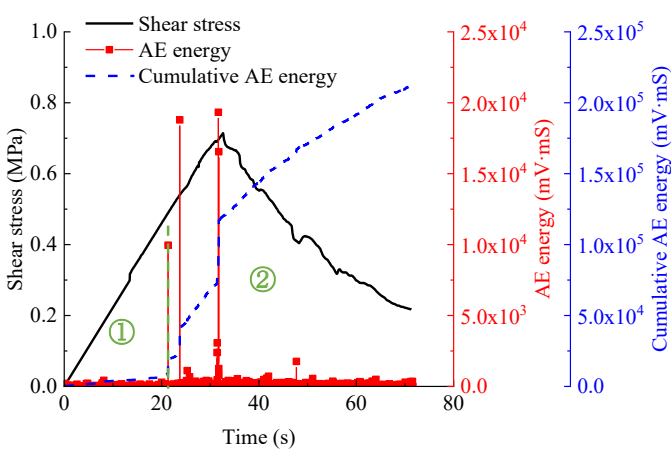

(c) Type III

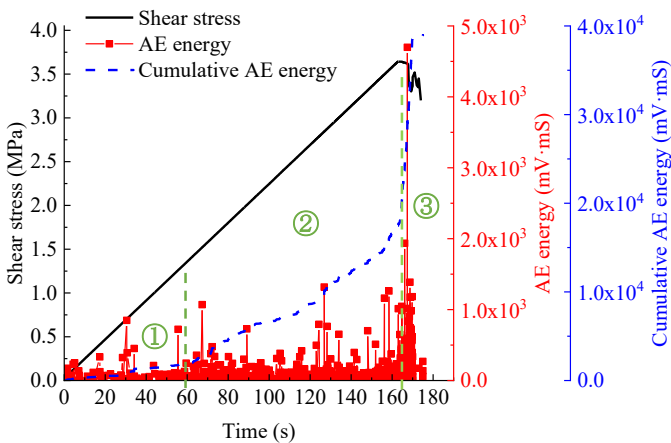

stress decreased sharply after reaching peak stress, and these specimens did not retain any residual strength. The sawtooth on the joint surface was cut off from its base, and the specimen failed.

Failure modes of the jointed specimens are a function of joint surface roughness and normal stress. Specimens with low roughness may exhibit local wear on the toothed surfaces or wear over a large area, whereas the tips or base of the sawtooth are cut off for specimens with high roughness. The specimen with low roughness subjected to high normal stress had the highest comprehensive shear resistance, whereas the specimen with high roughness subjected to high normal stress exhibited the worst damage.

\section{ACOUSTIC EMISSION EVALUATION}

AE monitoring is an essential approach to effectively evaluate the activity of micro-cracks in specimens and forecast macro-failures. The AE method was adopted to identify the four different types of shear failure modes. The AE energy is a state parameter that can reflect the instantaneous development of cracks, whereas the cumulative AE energy is a process parameter that indicates cumulative damage (Azinfar et al. 2019).

Figure 3(a) shows the AE energy characteristics of the rock-like jointed specimens. Both Type I and Type II modes of failure occur locally at sawtooth tips or sawtooth surfaces, whereas both Type III and Type IV failures involve much larger areas on the surfaces. Significant differences between the AE properties of the specimens under the effect of low and high normal stresses were observed.

(b) Type II

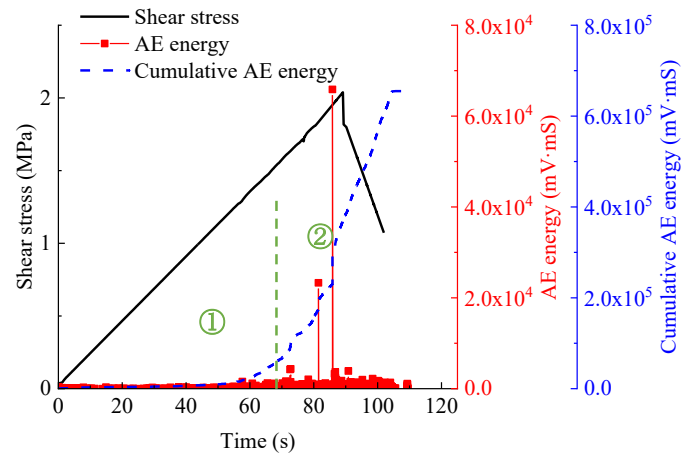

(d) Type IV

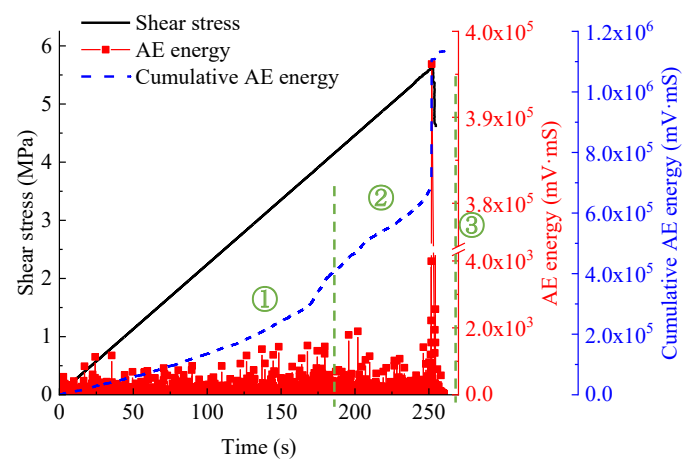


(e) $15^{\circ}$ specimen
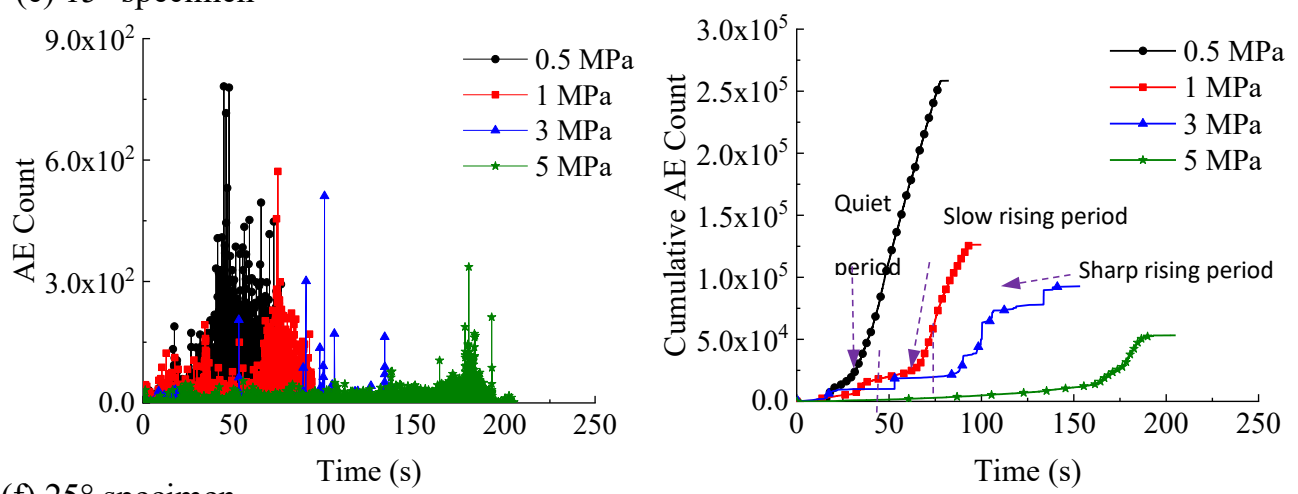

(f) $25^{\circ}$ specimen
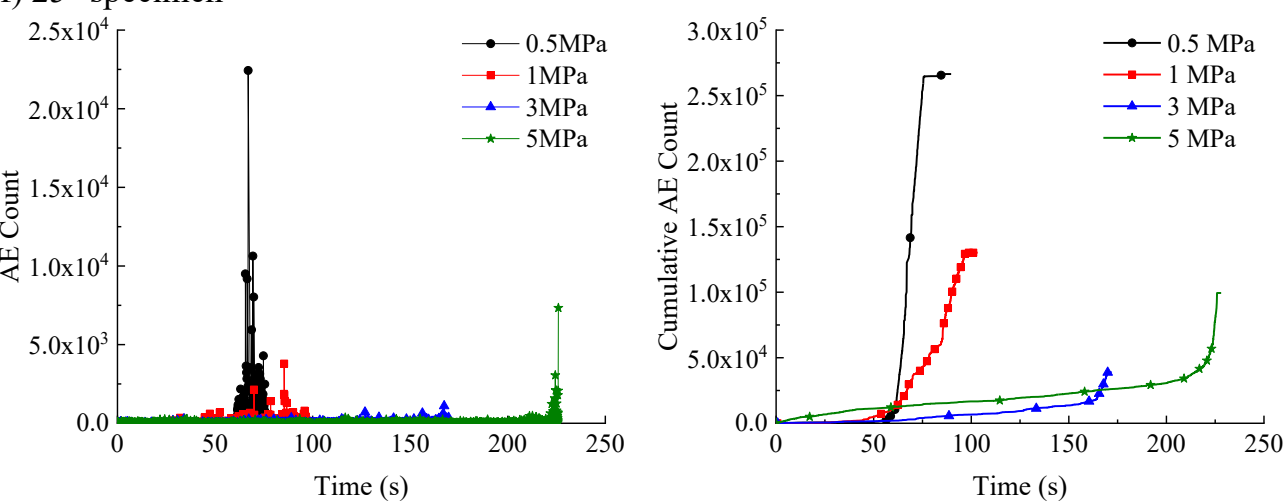

(g) $35^{\circ}$ specimen
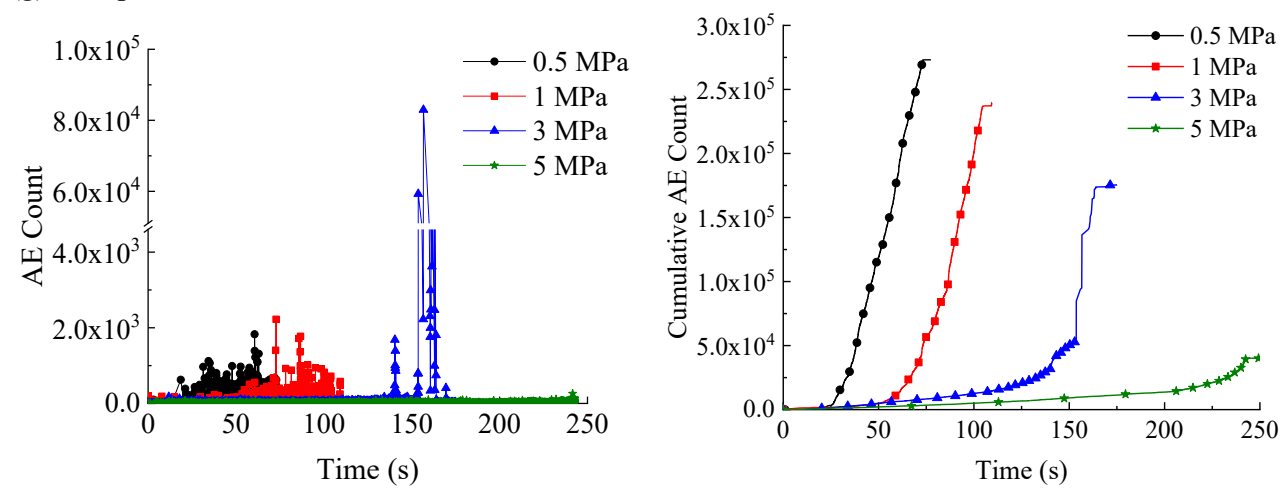

(h) $45^{\circ}$ specimen
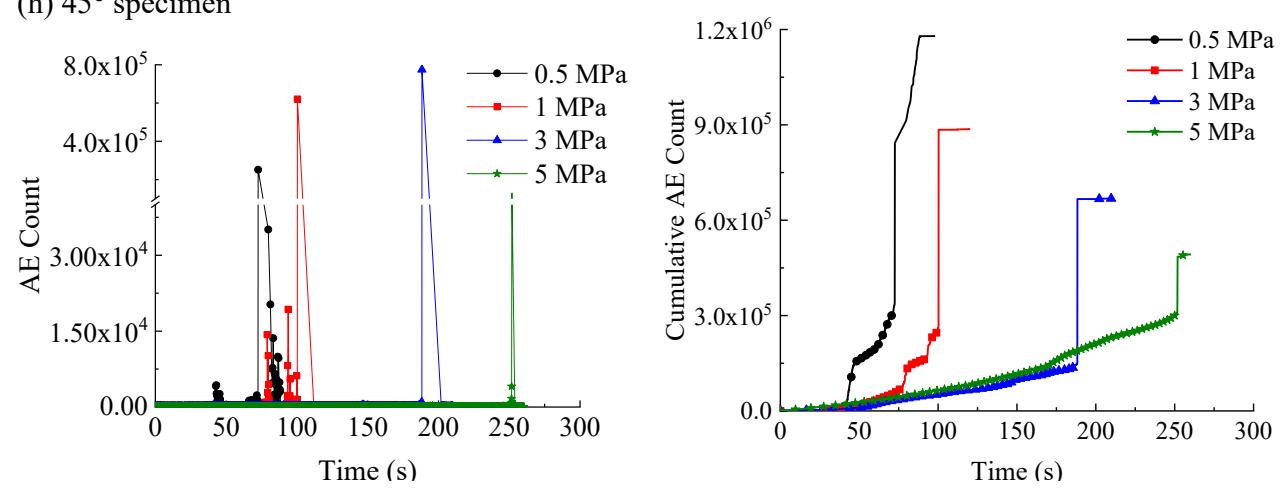

FIGURE 3. AE characteristics of the samples. The relationship among shear stress, time and AE characteristics exhibiting the four different kinds of shear failure modes

(a)-(d). Effects of normal stress on AE count and cumulative AE count (e)-(h) 
When subjected to low normal stress (Types I and II), the peak AE energy occurred before the peak shear strength, indicating that Types I and II failure modes occurred as a result of the accumulation of long-term crack activity. AE energy continued to be released after reaching the shear strength; thus, the cumulative AE energy gradually increased over time. The evolution of the cumulative AE energy was divided into two stages, as shown by the green dashed line in Figure 3 .

In the first stage, the cumulative AE energy gently increased. In the second stage, the cumulative AE energy quickly increased, and several surge points were observed. The rock bridge problem discussed by He et al. (2019) may account for this phenomenon. The rock bridge is the part of the material holding the opposing crack faces together; thus, this bridge is critically situated between the intact specimen and complete failure. Before reaching peak shear stress, the cracks initiate, propagate, and partially connect. After reaching peak shear stress, a large number of cracks connect, leading to continual AE energy release, and eventually causing the specimen to lose shear capacity. In this condition, the jointed rock exhibits plastic failure features.

When subjected to high normal stress (Types III and IV), peak AE energy occurs at the same time as peak shear stress or immediately thereafter. Cumulative AE energy curves were divided into three stages. The cumulative AE energy of these specimens gently increased, quickly increased, and then sharply increased. This finding indicates that specimens with Types III and IV failures exhibit brittle damage features.

Among these four types of failure modes, the total cumulative AE energy of the samples exhibiting Type IV failures was highest, whereas the total cumulative AE energy of the samples exhibiting the other three kinds of failures were the same order of magnitude. The most severe damage among all samples was observed in the $45^{\circ}$ jointed specimen under the effect of a $5 \mathrm{MPa}$ normal stress. Figure 3(b) shows the AE count and cumulative AE count characteristics of the specimens subjected to different normal stresses. An apparent moving and diffusing phenomenon was observed when comparing the specimens. When the roughness on the joint surface remained constant, the $\mathrm{AE}$ count pulse occurred later under higher normal stress (i.e. the testing time became longer), indicating that the shear resistance of the samples increased. Each of the cumulative AE count curves were divided into three stages: A quiet period, a slow rising period, and a sharp rising period. Measures should be taken to prevent the jointed rock mass from exhibiting shear failure along the joint surface in the slow rising period.

\section{NUMERICAL CALCULATION}

The PFC model was used to numerically simulate the shear failure process in the jointed rock samples. The PFC model is an assembly of circular particles of random sizes. Compared to the contact bond model, the parallel bond model is more suitable for depicting the mechanical characteristics of rock material (Asadi et al. 2012; Hazzard et al. 2002). Thus, the intact part of the model in the present study was established with the parallel bond model and the joint surface was established with linear parallel bond model. The mechanical behaviour of the particles is controlled by Newton's laws of motion. When the normal or shear force between the bond contacts exceeds the normal or shear strength, the bond will break, and a crack will be generated (Cai et al. 2007). The characteristics of crack initiation and propagation were monitored to interpret the failure mechanism of the jointed rock-like specimens.

Figure 4(a) shows the PFC model of a jointed specimen with a $15^{\circ}$ sawtooth. Eight walls were initially established to demarcate specimen boundaries and the sawtooth. The yellow dashed circles represent the calculation variables monitoring elements. Particles that contacted less than three surrounding particles were regarded as suspended particles. These particles were found and removed from the model to avoid calculation distortion. The test results of the $15^{\circ}$ jointed rock-like specimens subjected to a $0.5 \mathrm{MPa}$ normal stress were used to calibrate the parameter. The parameters of particles, linear parallel bond model and the linear model at the joint surface are listed in Tables 2-4, respectively. Figure 4(b) shows the shear stress-shear displacement curves of the simulated and experimental specimens, indicating that the input parameters simulated the experimental results well. (a)

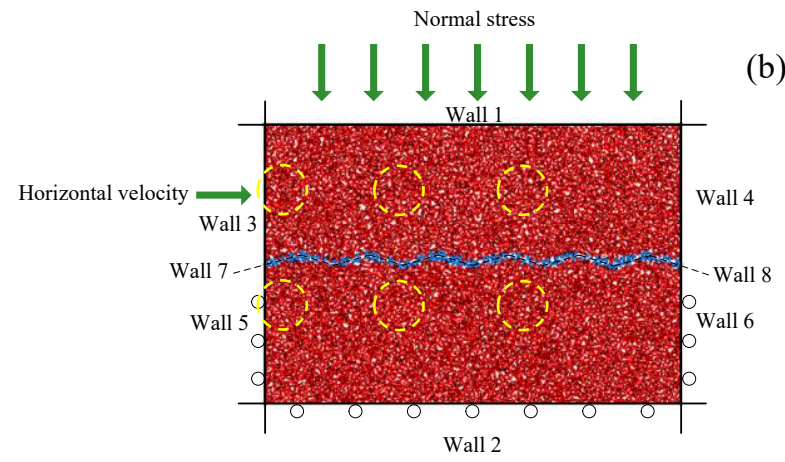

(b)

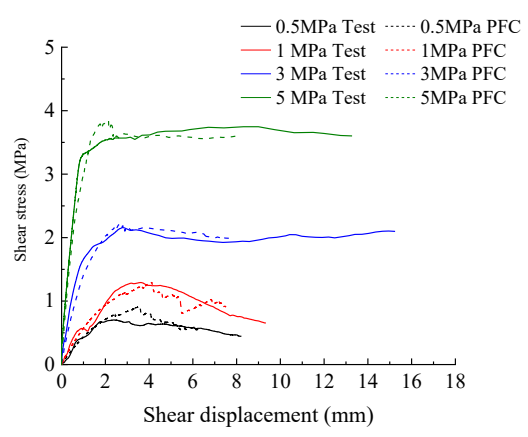

FIGURE 4. PFC model of a $15^{\circ}$ jointed specimen. (a) numerical simulation model. (b) Shear stress-shear displacement relationship. The yellow dashed circles represent the monitoring elements of the calculation variables 
TABLE 2. Particle parameters

\begin{tabular}{cc}
\hline Name & Value \\
\hline Porosity & 0.16 \\
Total number & 6990 \\
Minimum diameter $(\mathrm{mm})$ & 0.5 \\
Diameter ratio & 2.0 \\
Density $\left(\mathrm{kg} / \mathrm{m}^{3}\right)$ & 2750 \\
Local damp & 0.7 \\
\hline
\end{tabular}

TABLE 3. Linear parallel bond model parameters in intact speciment

\begin{tabular}{cc}
\hline Name & Value \\
\hline Contact normal stiffness $(\mathrm{N} / \mathrm{m})$ & $2.6 \times 10^{7}$ \\
Contact shear stiffness $(\mathrm{N} / \mathrm{m})$ & $2.9 \times 10^{7}$ \\
Friction coefficient & 0.57 \\
Bond normal stiffness $(\mathrm{Pa} / \mathrm{m})$ & $1 \times 10^{9}$ \\
Bond shear stiffness $(\mathrm{Pa} / \mathrm{m})$ & $1 \times 10^{9}$ \\
Tensile strength $(\mathrm{Pa})$ & $6 \times 10^{6}$ \\
Cohesion $(\mathrm{Pa})$ & $4 \times 10^{6}$ \\
Friction angle $\left({ }^{\circ}\right)$ & 30 \\
Bond gap interval $(\mathrm{m})$ & $5 \times 10^{-4}$ \\
\hline
\end{tabular}

TABLE 4. Linear model parameters at the joint surface

\begin{tabular}{cc}
\hline Name & Value \\
\hline Contact normal stiffness $(\mathrm{N} / \mathrm{m})$ & $2.6 \times 10^{7}$ \\
Contact shear stiffness $(\mathrm{N} / \mathrm{m})$ & $2.9 \times 10^{7}$ \\
Friction coefficient & 0.15 \\
\hline
\end{tabular}

The lower part of the specimen was kept stationary. The normal stress was vertically applied to the upper part of the specimen and the load was kept constant by the means of servo-control (Bahaaddini 2017). The horizontal velocity of $0.3 \mathrm{~mm} / 10^{6}$ steps was small enough to ensure the quasi-static equilibrium statement.

Figure 5 shows the four different shear failure modes of the jointed rock-like specimens, in which the red lines represent tensile cracks and the blue lines represent shear cracks. The results showed the micro-damage mechanism from the perspective of crack nucleation, propagation, and coalescence. Regardless of the failure mode, microtensile cracks were the dominant form of damage in the jointed specimens. 

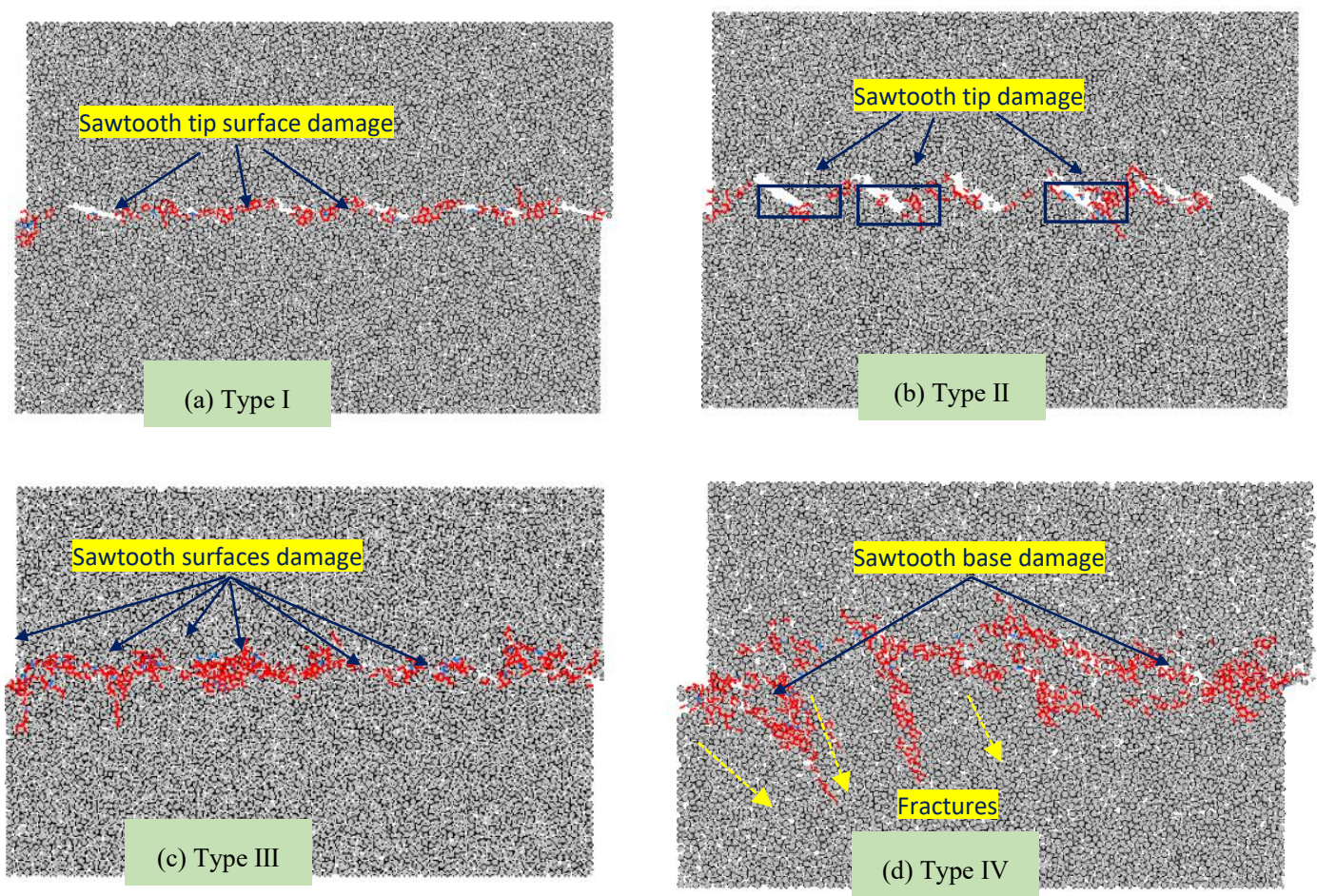

FIGURE 5. Failure mechanism of the four different modes simulated via PFC

In Figure 5(a), there is obvious dilatancy for the $15^{\circ}$ specimen under low normal stress. Only a few cracks emerged around the sawtooth tips. Because these cracks were local and not connected with each other, the triangular sawtooth was worn on the tips (i.e. Type I damage).

In Figure 5(b), the upper part of the $35^{\circ}$ specimen overrode the sawtooth in the lower part, and the dilatancy was more obvious than that in the $15^{\circ}$ specimen (Figure 5(a)). Cracks were distributed over the sawtooth tips, including the surface and interior. These cracks were connected, resulting in the sawtooth tips being cut off. The cracks distributed on the sawtooth surfaces did not connect with the cracks in the sawtooth interior and developed into surface wear. Although Type II failure was dominant, sawtooth surface wear always occurred.

In Figure 5(c), under the effect of high normal stress, the dilatancy phenomenon was no longer noticeable as the dilation angle increases. Compared with the $15^{\circ}$ specimen under low normal stress, the Type III specimen had a greater total number of cracks. Most of these cracks were distributed over the entire sawtooth surface, and only a small portion of cracks extended into the interior of the specimen.
In Figure 5(d), when the $45^{\circ}$ specimen was subjected to the highest normal stress $(5 \mathrm{MPa})$, serious severe occurred to this specimen, and the dilation was the smallest. In addition to a large number of cracks distributed on the sawtooth tips and surfaces, the cracks at the sawtooth surfaces coalesced with cracks deep in the specimen's interior. Thus, three large shear damage bands formed, as indicated by the yellow arrows in Figure 5. Under the effect of shear stress and fractures, this specimen exhibited the longest shear displacement immediately after the specimen broke down. The simulation results were also observed in the work of Bahaaddini (2017).

Dilation is highly related to the dilation angle and normal stress. For failure modes Types I and II, relatively large dilation was observed under low normal stress. For failure modes Types III and IV, under the effect of high normal stress, the dilation decreased as the normal stress concentrated in the opening of a large tensile crack. The dilation decreases and the surface resistance increases when the dilation angle increases or the normal stress increases. 
FAILURE MECHANISM OF THE JOINTED SPECIMENS WITH AN IRREGULAR PROFILE

In this section, the established $\mathrm{PFC}^{2 \mathrm{D}}$ model was further modified to simulate the deformation and damage properties of a jointed specimen with an irregular profile.
One of the 10 standard roughness profiles proposed by Barton and Choubey (1977), JRC = $14-6$, was used to establish the irregular joint morphology. The $J R C=14-6$ profile is shown in Figure 6(a). (a)

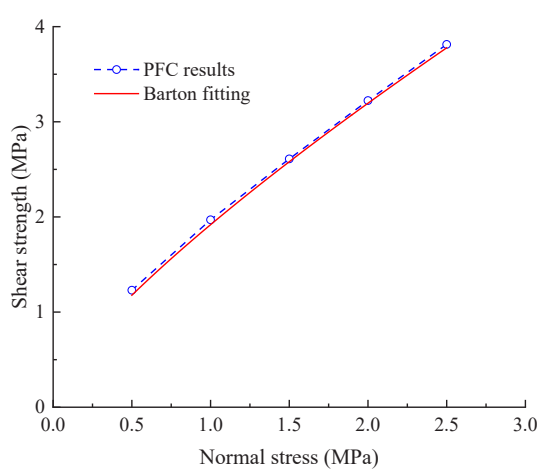

(c) (b)
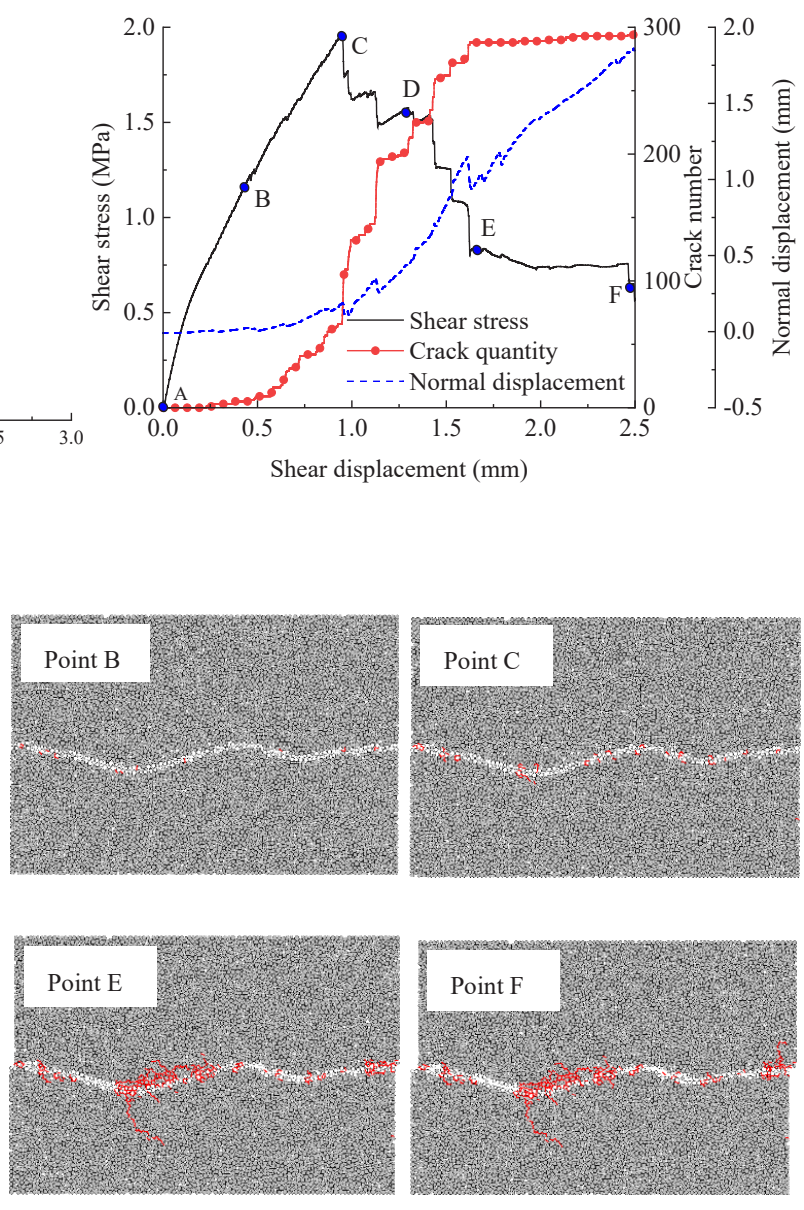

(d)
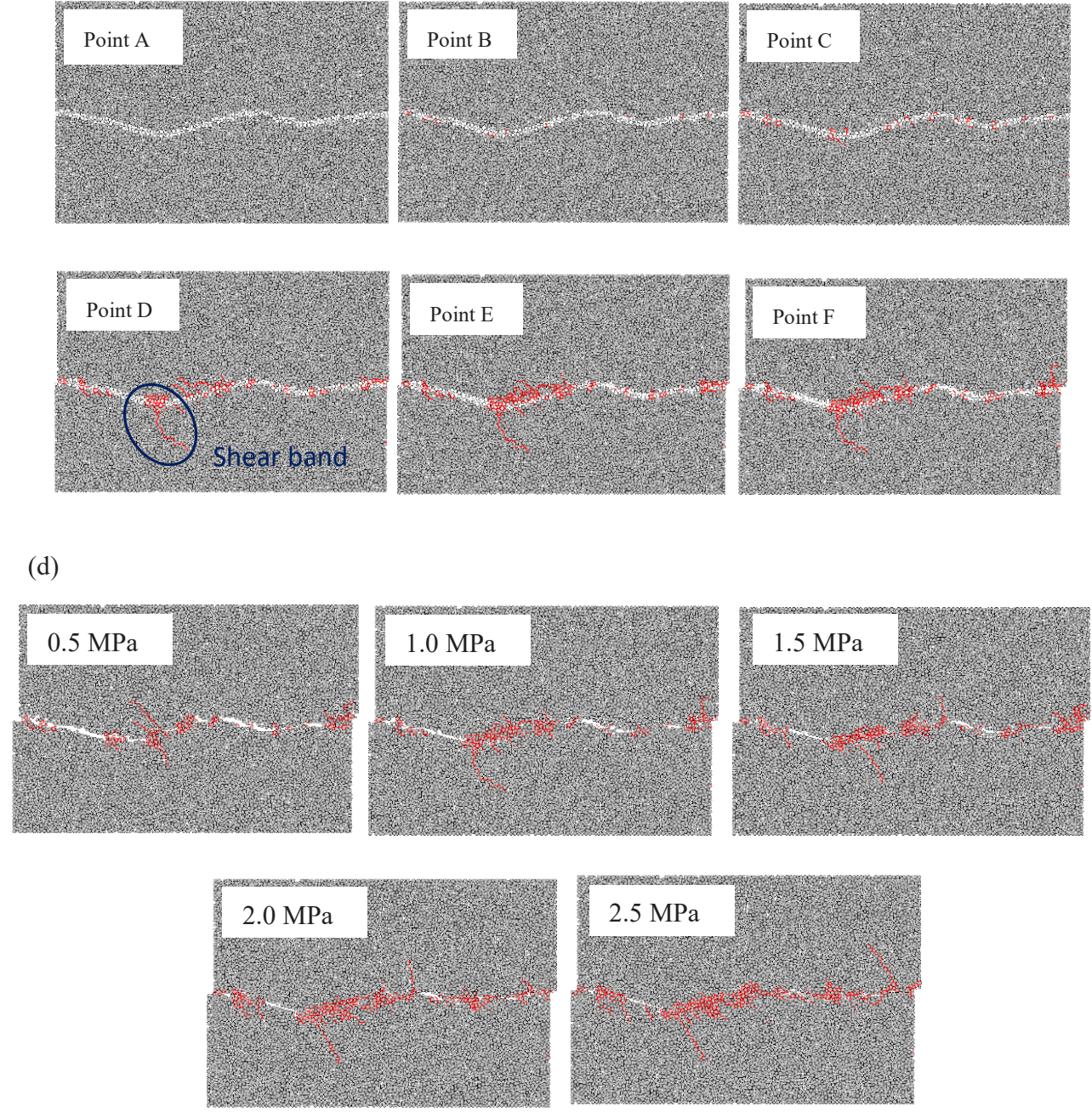

FIGURE 6. Simulation results. Comparing the shear strength-normal stress relationship from the PFC simulation and the theoretical Barton model (a). Shear stress, crack quantity and normal displacement vs. shear displacement (b). Crack development process of the jointed specimen with an irregular profile (c). Crack distribution in the specimens with an irregular joint profile under different normal stresses (d) 
Direct shear tests were performed under normal stress of 1.0 MPa. The shear strength from the PFC simulation was compared with that from the Barton and Bandis joint shear strength model in (1). As shown in Figure 6(b), the shear strength-normal stress relationship from the PFC and shear tests are well fitted.

$$
\tau=\sigma \tan \left[J R C \lg \left(\frac{J C S}{\sigma}\right)+\varphi_{r}\right]
$$

where $J R C$ is the joint roughness coefficient, JCS is the compressive strength (10 MPa according to the uniaxial compression simulation test), and $\varphi_{r}$ is the residual internal friction angle, which was determined to be $30^{\circ}$ via a direct shear test on a flat joint specimen.

To fully study the development of cracks and the shear failure mechanisms in the irregularly jointed specimens, six characteristic points were selected on the shear stressshear displacement curve (Figure 6(c)): Point A is the starting point, $\mathrm{B}$ is the shear displacement of $0.5 \mathrm{~mm}, \mathrm{C}$ is the shear stress peak point, $\mathrm{D}$ is the shear displacement of $1.3 \mathrm{~mm}, \mathrm{E}$ is the shear displacement of $2 \mathrm{~mm}$, and $\mathrm{F}$ is the finishing point. From the combination of Figure 6(c) and the crack development process in Figure 6(d), the cracking behaviours can be concluded.

Before point $\mathrm{C}$ (i.e. before peak shear stress), the cracks were mainly distributed on the sawtooth surfaces, and the quantity of cracks increased slowly. At point $\mathrm{C}$, a sharp increase was detected in the curve of crack quantity. Afterwards, the cracks on the sawtooth surfaces and in the interior of the specimen connected quickly, as shown at point $\mathrm{D}$. From point $\mathrm{C}$ to point $\mathrm{E}$, the shear stress continued to decrease, while the crack quantity continued to increase, indicating that the cracks grew and coalesced on a large scale, which can be seen in Figure 6(d). A shear band formed during this period, which contributed to the final failure of the specimen. After point E, the crack quantity stabilised. The crack activity in the specimen stopped, and dilatancy was observed.

Numerical direct shear tests on this irregularly jointed specimen were also carried out under normal stresses of $0.5,1.5,2.0$, and $2.5 \mathrm{MPa}$ to examine the effect of normal stress. As shown in Figure 6(e), the increase in normal stress corresponded to increases in the total quantity of cracks. Shear bands always existed at the location of high asperities. At points of severe roughness, the asperity tips were cut off under low normal stress, whereas long fractures at asperity bases led to the asperity bases being cut off under high normal stress. At points of less severe roughness, wear occurred on the asperity tips under low normal stress, whereas wear occurred over asperity surfaces under high normal stress.

\section{CONCLUSION}

Multiple measures, including direct shear tests, AE monitoring, and PFC numerical simulation, were conducted on rock-like jointed specimens (cement mortar). Regular triangular sawtooth were designed to simulate roughness on the joint surface. The influence of dilation angle and normal stress on the failure, AE parameter characteristics, and crack development processes were investigated. In addition, the failure mechanism of a joint with an irregular profile was also analysed. The following primary conclusions were drawn from these results:

There were four types of failure modes: Type I: when the shear specimen had a small dilation angle, the sawtooth tips were slightly worn under low normal stress. Type II: when the shear specimen had a large dilation angle, the sawtooth tips were cut off under low normal stress. Type III: when the shear specimen had a small dilation angle, the sawtooth surfaces were worn over a large area under high normal stress. Type IV: when the shear specimen had a large dilation angle, the sawtooth on the joint surfaces was generally cut off from the sawtooth base under high normal stress. Specimens exhibiting Type IV failure did not retain any residual shear strength, and the damage in these specimens was sudden and severe. The failure mode of the jointed rock-like specimen was controlled by the combination of normal stress and joint roughness.

AE parameters, including the AE count and energy, could effectively determine the failure modes. Under low normal stress, local damage occurred on the sawtooth tips and surfaces, and the AE energy curves continued to increase after reaching peak shear stress. Under high normal stress, more severe damage occurred on sawtooth surfaces and bases on a large scale, and the AE energy curves decreased immediately after reaching peak shear stress.

As the normal stress increased, the AE energy and cumulative AE count peak time were delayed. Increasing normal stress can enhance overclosure between the upper and lower surfaces of the specimen, thereby improving the specimen's shear capacity.

Initiation, propagation, and coalescence of cracks were modelled using PFC, which showed the damage mechanism of the four failure modes. A small number of cracks were distributed on the surfaces of sawtooth tips in Type I damage. When the horizontal cracks on the sawtooth tips connected with each other, or the cracks on the joint surfaces coalesced with those in the interior of the specimen, Type II damage was detected. When normal stress increased, the cracks spread across the entire sawtooth surface, and Type III damage occurred. The worst situation occurred when these cracks simultaneously 
extended to the intact specimen, and the sawtooth was cut off from its base causing Type IV damage.

\section{ACKNOWLEDGEMENTS}

This research was funded by the National Natural Science Foundation of China (51008319, 51779021), Scientific and Technological Research Program of Chongqing Municipal Education Commission (KJQN201902504).

\section{REFERENCES}

Asadi, M.S., Rasouli, V. \& Barla, G. 2012. A bonded particle model simulation of shear strength and asperity degradation for rough rock fractures. Rock Mechanics and Rock Engineering 45(5): 649-675.

Azinfar, M.J., Ghazvinian, A.H. \& Nejati, H.R. 2019. Assessment of scale effect on 3D roughness parameters of fracture surfaces. European Journal of Environmental and Civil Engineering 23(1): 1-28.

Bahaaddini, M. 2017. Effect of boundary condition on the shear behaviour of rock joints in the direct shear test. Rock Mechanics and Rock Engineering 50(5): 1141-1155.

Ban, Y., Fu, X. \& Xie, Q. 2020. Revealing the laminar shale microdamage mechanism considering the relationship between fracture geometrical morphology and acoustic emission power spectrum characteristics. Bulletin of Engineering Geology and the Environment 79(2): 1083-1096.

Bandis, S.C., Lumsden, A.C. \& Barton, N.R. 1983. Fundamentals of rock joint deformation. International Journal of Rock Mechanics and Mining Sciences \& Geomechanics Abstracts 20(6): 249-268.

Barton, N. 1973. Review of a new shear-strength criterion for rock joints. Engineering Geology 7: 287-332.

Barton, N., Bandis, S. \& Bakhtar, K. 1985. Strength deformation and conductivity coupling of rock joints. International Journal of Rock Mechanics and Mining Sciences \& Geomechanics Abstracts 20(3): 121-140.

Barton, N. \& Choubey, V. 1977. The shear strength of rock joints in theory and practice. Rock Mechanics and Rock Engineering 10(1-2): 1-54.

Cai, M., Kaiser, P.K., Morioka, H., Minami, M., Maejima, T., Tasaka, Y. \& Kurose, H. 2007. FLAC/PFC coupled numerical simulation of ae in large-scale underground excavations. International Journal of Rock Mechanics and Mining Sciences 44(4): 550-564.

Casagrande, D., Buzzi, O., Giacomini, A., Lambert, C. \& Fenton, G. 2018. A new stochastic approach to predict peak and residual shear strength of natural rock discontinuities. Rock Mechanics and Rock Engineering 51(1): 69-99.

Cho, N., Martin, C.D. \& Sego, D.C. 2008. Development of a shear zone in brittle rock subjected to direct shear. International Journal of Rock Mechanics and Mining Sciences 45(8): 1335-1346.

Cui, Y. 2019. Effect of joint type on the shear behavior of synthetic rock. Bulletin of Engineering Geology and the Environment 78(5): 3395-3412.

$\mathrm{Fu}, \mathrm{X}$., Xie, Q. \& Liang, L. 2015. Comparison of the Kaiser effect in marble under tensile stresses between the Brazilian and bending tests. Bulletin of Engineering Geology and the Environment 74(2): 535-543.

Giwelli, A.A., Sakaguchi, K., Gumati, A. \& Matsuki, K. 2014. Shear behaviour of fractured rock as a function of size and shear displacement. Geomechanics and Geoengineering 9(4) 253-264.

Grasselli, G., Wirth, J. \& Egger, P. 2002. Quantitative threedimensional description of a rough surface and parameter evolution with shearing. International Journal of Rock Mechanics and Mining Sciences 39(6): 789-800.

Gu, X.F., Seidel, J.P. \& Haberfield, C.M. 2003. Direct shear test of sandstone-concrete joints. International Journal of Geomechanics 3(1): 21-33.

Hazzard, J.F., Collins, D.S., Pettitt, W.S. \& Young, R.P. 2002. Simulation of unstable fault slip in granite using a bondedparticle model. Pure and Applied Geophysics 159(1): 221245.

He, J., Pasternak, E. \& Dyskin, A. 2019. Bridges outside fracture process zone: Their existence and effect. Engineering Fracture Mechanics 225: 106453.

Khazaei, C., Hazzard, J. \& Chalaturnyk, R. 2015. Damage quantification of intact rocks using acoustic emission energies recorded during uniaxial compression test and discrete element modeling. Computers and Geotechnics 67: 94-102.

Liu, Z., Jia, J.S., Feng, W, Ma, F. \& Zheng, C. 2017. Shear strength of cemented sand gravel and rock materials. Sains Malaysiana 46(11): 2101-2108.

Liu, X.R., Kou, M.M., Lu, Y.M. \& Liu, Y.Q. 2018. An experimental investigation on the shear mechanism of fatigue damage in rock joints under pre-peak cyclic loading condition. International Journal of Fatigue 106: 175-184.

Meier, T., Rybacki, E., Backers, T. \& Dresen, G. 2015. Influence of bedding angle on borehole stability: A laboratory investigation of transverse isotropic oil shale. Rock Mechanics and Rock Engineering 48(4): 1535-1546.

Mpalaskas, A.C., Matilzas, T.E., Van Hemelrijck, D., Papakitsos, G.S. \& Aggelis, D.G. 2016. Acoustic emission monitoring of granite under bending and shear loading. Archives of Civil and Mechanical Engineering 16: 313-324.

Muralha, J., Grasselli, G., Tatone, B., Blümel, M., Chryssanthakis, P. \& Yujing, J. 2014. ISRM suggested method for laboratory determination of the shear strength of rock joints: Revised version. Rock Mechanics and Rock Engineering 47: 291-302.

Oh, J. \& Kim, G.W. 2010. Effect of opening on the shear behavior of a rock joint. Bulletin of Engineering Geology and the Environment 69(3): 389-395.

Park, J.W. \& Song, J.J. 2009. Numerical simulation of a direct shear test on a rock joint using a bonded-particle model. International Journal of Rock Mechanics and Mining Sciences 46(8): 1315-1328.

Patton, F.D. 1966. Multiple modes of shear failure in rock. In Proceedings of the 1st Congress on International Society for Rock Mechanics Lisbon, Portugal. pp. 509-513.

Rafek, A.G. \& Goh, T.L. 2014. Correlation of joint roughness coefficient (JRC) and peak friction angles of discontinuities of Malaysian schists. Sains Malaysiana 43(5): 751-756. 
Rafek, A.G., Ong, B.C. \& Goh, T.L. 2019. Geomechanical characterisation of rock mass and slope stability analysis at Laman Granview, Saujana Puchong, Selangor, Malaysia. Sains Malaysiana 48(4): 757-763.

Serasa, A.S., Lai, G.T., Rafek, A.G., Hussin, A., Khai Ern, L. \& Mohamed, T.R. 2017. Peak friction angle estimation from joint roughness coefficient of discontinuities of limestone in Peninsular Malaysia. Sains Malaysiana 46(2): 181-188.

Shrivastava, A.K. \& Rao, K.S. 2018. Physical modeling of shear behavior of infilled rock joints under CNL and CNS boundary conditions. Rock Mechanics and Rock Engineering 51(1): 101-118.

Wang, G., Zhang, Y., Jiang, Y., Liu, P., Guo, Y., Liu, J., Ma, M., Wang, K. \& Wang, S. 2018. Shear behaviour and acoustic emission characteristics of bolted rock joints with different roughnesses. Rock Mechanics and Rock Engineering 51(6): 1885-1906.

Zhang, X., Lu, Y., Tang, J., Zhou, Z. \& Liao, Y. 2017. Experimental study on fracture initiation and propagation in shale using supercritical carbon dioxide fracturing. Fuel 190: 370-378.

Zhou, X.P., Zhang, J.Z. \& Wong, L.N.Y. 2018. Experimental study on the growth, coalescence and wrapping behaviors of 3D cross-embedded flaws under uniaxial compression. Rock Mechanics and Rock Engineering 51(5): 1379-1400.

Yuxin Ban, Qiang Xie* \& Jingjing Wang

School of Civil Engineering

Chongqing University

400044 Chongqing

People's Republic of China
Qiang Xie*

Key Laboratory of New Technology for Construction of Cities in Mountain Area (Chongqing University)

Ministry of Education

400044 Chongqing

People's Republic of China

Xiang $\mathrm{Fu}^{*}$

College of River and Ocean Engineering

Chongqing Jiaotong University

400074 Chongqing

People's Republic of China

Rini Asnida Abdullah

School of Civil Engineering

Faculty of Engineering

Universiti Teknologi Malaysia

81310 Johor Bahru, Johor Darul Takzim

Malaysia

*Corresponding author; email: xieqiang2000@163.com

Received: 7 March 2020

Accepted: 2 August 2020 